International Research Journal of Engineering, IT \& Scientific Research
Available online at https://sloap.org/journals/index.php/irjeis/
Vol. 6 No. 1, January 2020, pages: 18-30
ISSN: 2454-2261
https://doi.org/10.21744/irjeis.v6n1.848

\title{
Implementation Strategies for Homework Sent
}

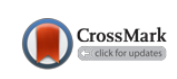

\author{
María Tamara Vera Moreira ${ }^{a}$ \\ Ana María Velásquez Saldarriaga ${ }^{b}$ \\ Génesis Karina Zambrano Mendoza ${ }^{c}$ \\ María Valentina Loor Santos ${ }^{\mathrm{d}}$ \\ Douglas José Giler Loor ${ }^{\mathrm{e}}$
}

Article history:

Submitted: 27 November 2019

Revised: 18 December 2019

Accepted: 22 January 2020

\section{Keywords:}

curricular adjustments;

Ecuadorian educational reality;

educational reforms;

educational system;

teaching-learning;

\begin{abstract}
The research was redirected to the different studies that focus on reality of the Ecuadorian education system and the disadvantages facing the teaching-learning process due to negative manifestations of the environment, which influence the academic performance of the students, considering that precarious economic situations, intra-family problems, the barriers that the teacher faces Due to lack of recreational, recreational resources, training based on various areas of study, there are some situations that create inequalities between the different educational contexts of the country, being necessary to look for alternative solutions or reforms that focus on a particular reality, where it is distinguished the stages I of the rural and urban area, establishing as an objective to analyze education from an aspect of transformation, through a pedagogical plan determined by curricular adjustments, which allow the development of skills, implementation of methods, techniques according to the required level, with the purpose of Obtain educational excellence. For the development of the study, the exploratory methodology linked to knowing the specific problem was used, based on theoretical bases and results made in other fields of inquiry that relate the situation of the school to respond to social, cultural, economic and educational interests.
\end{abstract}

International research journal of engineering, IT \& scientific research (C) 2020. This is an open access article under the CC BY-NC-ND license (https://creativecommons.org/licenses/by-nc-nd/4.0/).

\section{Corresponding author:}

María Tamara Vera Moreira,

Master's Student of the Pontificia Universidad Católica del Ecuador, Sede Manabí, Portoviejo.

Email address: mvera5746@pucem.edu.ec,tamyveramoreira@gmail.com

\footnotetext{
a Pontificia Universidad Católica Del Ecuador, Sede Manabí, Portoviejo, Ecuador

${ }^{\mathrm{b}}$ Pontificia Universidad Católica Del Ecuador, Sede Manabí, Portoviejo, Ecuador

c Pontificia Universidad Católica Del Ecuador, Sede Manabí, Portoviejo, Ecuador

${ }^{d}$ Pontificia Universidad Católica Del Ecuador, Sede Manabí, Portoviejo, Ecuador

e Pontificia Universidad Católica Del Ecuador, Sede Manabí, Portoviejo, Ecuador
} 


\section{Introduction}

Education is a fundamental pillar in every society because it allows for continuous and effective preparation, which is not only evidenced in the educational institutions, but also in the investigations of different topics addressed at present, being of great contribution to the community in order to investigate problems or issues that exist and that thanks to inquiries you can acquire information and analyze the educational reality from different perspectives. Education in society is important due to the experiences that are achieved during the teaching-learning process in order to solve problems in different areas, the educational reality focuses on people learning differently, training in Ecuador It has advanced significantly thanks to the growing development of science and technology, which has become indispensable in the realization and fulfillment of academic activities.

The educational process focuses on learning, professional performance, teaching methods, and techniques, wherever the continuous research of students is involved. According to Hernández (2015), the different learning styles and factors that students have to learn as the skills and abilities must be taken into account, otherwise, the potential of each person cannot be developed and as a consequence will affect the academic performance. The educational quality improves through good teaching practices that are accompanied by content according to the appropriate educational level and the development that students have in the classroom. The development of skills, competencies, skills, attitudes and aptitudes make people develop in any educational, social, cultural, political or economic field; In order to meet the objectives needed to form society and contribute to the good of the country, an analysis of the educational reality of Ecuador is carried out from different points of view and opinions, comparisons are detailed and the progress of the last years.

Thanks to the education that is acquired, it is reflected that society every day is prepared to transcend to other educational environments and argue in any context whether positive or negative; It would not be possible without the remarkable progress that has been presented during all this time, which has been gratifying for society, observing that the level of competitiveness increases with the use of resources that help to acquire knowledge and skills to perform competent pedagogical actions. Students who obtain a bachelor's degree are able to develop competencies corresponding to their level of academic training, which allows them to address professional interests and develop in different educational dimensions; On the other hand, the curriculum that the Ministry of Education imposes may be adaptable, but there are limitations in carrying out academic activities. According to Erreyes et al. (2017), they affirm that the only problem presented by education is that there is no structural coherence between the different educational levels such as Initial, Basic, Baccalaureate and Higher Education. The lack of organization and coordination is one of the great factors that have a negative impact on education, it is the lack of sequencing that prevents reaching the educational objectives set.

Learning in the country has been a priority and has generated uncertainty, which in one way or another has benefited the teaching of Ecuador, through teaching practices it can be seen that the reality of it has evolved, however, they do not apply the same techniques and strategies in the educational media, because it depends on the level of the students, the environment that is developed and the content that is taught, highlighting that each group of students learns in different ways, therefore, when talking about this topic must take into account all the aspects that affect it, highlighting the importance of emphasizing resources and the constant practices used in the class. It is necessary that education is focused on scientific research, which helps the educational community to increase interest in improving and achieving everything established in the school environment. According to Murillo \& Garrido (2019), they affirm that research is important to obtain educational quality, it contributes and helps in decisionmaking for the solution of problems considering the educational levels in which they develop.

Through previous research, it has been possible to study the different factors that affect educational reality and how it improves as time goes by. According to Merchán (2018), it makes reference that since 2017, starting from the government of the economist Rafael Correa, important changes in the organizational structure of Ecuadorian education were promoted, such as the unification of the educational system and the process of dismantling the intercultural bilingual system. Taking as an initiative to have a better organization and that is beneficial for the educational community, which has given good results where the progress of those educated in different areas of studies is evidenced. The objective of this article is to analyze the Ecuadorian educational reality and as the transformations have been at present, taking as an action field the Educational Unit "Areliza Vera Góngora", the analysis on Ecuadorian education and the problems it faces, is detailed use of didactic resources for the development of skills during the teaching-learning process, the factors of academic achievement, causes of education and various innovations that help in the quality of education, being part of current teaching in order to provide solutions to

Moreira, M. T. V., Saldarriaga, A. M. V., Mendoza, G. K. Z., Santos, M. V. L., \& Loor, D. J. G. (2020). Implementation strategies for homework sent. International Research Journal of Engineering, IT \& Scientific Research, 6(1), 18-30. https://doi.org/10.21744/irjeis.v6n1.848 
situations that arise in the different educational spaces, theoretically based on the contributions of previously conducted research (Meneses et al., 2020). The educational reality of Ecuador presents changes for the good of society, identifying traditional teaching through an updated approach to new class methodologies, to train knowledge leaders, capable of generating solutions for the well-being of the environment, that is, educational reforms and the advancement of technology positively influence the teaching-learning processes and promote quality education (López et al., 2020).

\section{Materials and Methods}

The methodology used to employ research is through the exploratory and bibliographic method, applied in the Educational Unit "Areliza Leonor Vera Góngora" focusing on a real and effective search of the main characteristics of the problem, based on documentary sources, magazines, books, thesis for the collection of information, to support the study to obtain specific knowledge and ideas defined on current educational systems and act through improvement proposals that provide quality education (Hérnandez et al., 2010). The research of an exploratory nature will allow us to understand the problem from different perspectives, through the interpretation of research focused on similar studies carried out in different contexts, and its objective is to examine a topic that has not been analyzed to clear doubts and intervene with solutions that respond to the situation. The bibliographic method manages the investigation sequentially, about the situations that determine the current education and the participation of the educational community, analyzing the existing information in different locations, considering topics that provide a feasible exploration and serve as a basis for future studies.

\section{Results and Discussions}

According to the bibliography consulted, the following data were obtained:

\subsection{The current educational system}

Nowadays states constantly value pedagogical procedures, to know multidimensionality and to interact and change the axes of learning, maintaining scientific research, evaluations, and hard sciences as essential aspects of quality education, to which educational excellence is attributed, considering that current education eludes soft sciences, innate skills and life experiences learned in the environment, interrelating different theories of the functions of the educational systems (Klaric, 2017; Macías et al., 2018) in the documentary a crime called education reveals a deep analysis carried out in 14 countries, where it checks different realities in each regime, comparing nations that lead in the educational field, but the students are immersed in various problems that affect emo health national caused by stress, tension, perfectionism, bullying and nations that have an average level manifesting education in Latin America as deficient, the result of a difficult family context, absent parents, socio-economic aspects and low cultural level.

Carrying out an analysis from the American continent, it can be mentioned that education has undergone a series of transcendental changes over time, evidencing that currently the training processes aim to achieve social and school inclusion in order to seek strategies that provide equal opportunities regardless of the social extract to which it belongs (Martínez \& Torrego, 2014). It is important to consider that the different educational systems analyzed in the various investigations carried out, converge on criteria that lead to having a clear objective to achieve quality education, placing the human being as a priority within the teaching-learning processes, which must be supported by a direct way through the states.

\subsection{Ecuadorian educational reality}

Analyzing the educational context from its genesis, it can be evidenced the series of changes to which it has been subjected, due to the different visions that from its regulatory entity has been addressed, the result of this is traditional education, which evidences The main characteristics are the firmness and rigor of the teacher in both personal and academic fields, making the student a passive and receiving entity, being the sole owner of the truth the teacher (Salgado, 2016; Alava \& Martinez, 2019). The different learning scenarios determine teaching within the 
country, focused on educational guidelines undertaken by innovation, development, participation of the educational community, composed of parents, students, and teachers, a structure that shows technological, cultural, social, economic changes and morals that promote an education that supports the teaching-learning process for the improvement of the education system.

The manifestations of an Ecuadorian educational reality are standardized tests, rigid working hours, high percentage of bureaucratic work and equal teaching towards students without visualizing the different skills or competencies, knowing the variables that negatively influence the teaching-learning process it allows acting and seeking alternative solutions through strategies, methods or techniques that contribute to educational development (Fernandez et al., 2017). As proposals for changes in the education regime, there are studies that lead education to new approaches, where the process relies on didactic and technological resources, methods, techniques, strategies according to the levels and abilities of the student, to strengthen the acquired skills and train people able to function in various fields that promote the progress of society. One of the recent changes promoted by the Ministry of Education of Ecuador (MINEDUC) is the proposal of a flexible curriculum, which seeks alternative solutions thinking of the teacher and student, establishing a work aimed at transversal axes, essential and desirable skills, thought to guide the students from their formation to the exit profile of the Ecuadorian high school students which is innovative, fair and supportive (Granda, 2018).

\section{Analytical approach to current education}

The various changes and new trends show a submerged education within several competent political and economic scenarios, which determine the educational field within an important hierarchical level for society, where the main role is to improve the educational quality thinking about the holistic and humanistic formation of the human being, being necessary to mention that several authors such as Isch (2011), determine that in recent times part of the responsibility of the state has been delegated to private institutions which in exchange for money They generate a better quality education. There are many factors that intervene in the development of education, from the state side, the economic feasibility of the family, social environment in which it develops, the will of those who do education and predisposition of students, among others are determining realities that promote an educational system aimed at success or failure.

\section{Education of society and knowledge}

Education is the source of development that governs a society, determined as a process that guides teaching-learning to discover skills in learners, through pedagogical work linked to support in ethical and moral values within of a classroom, with the purpose of forming critical, self-efficient, humanistic people leading to a vision of continuous improvement, based on studies analyzed by several authors about how the current education system works (Diaz, 2018), declares that the new innovative trends frame a before and after of the formative culture, where changes must be made towards the entire educational community made up of parents, teachers and students creating new perspectives in the way of conceiving knowledge. With the insertion of globalization in today's society, it is determined that technology has been inserted significantly in the educational field, which generates a series of changes from teachers to students, considering that teachers are currently migrants digital while the current generation is considered as digital natives, an aspect that makes a specific difference that should be considered when performing different activities. It is indisputable to talk about education without manifesting the innovations and relevant aspects that interact in the knowledge society, with the firm certainty of forming research entities with the fundamental characteristic of showing alternative changes for the development and progress of a country.

\section{Modernity and education}

Globalization is one of the symbolic manifestations that characterize a new system, where innovation is leaving aside the promotion of values so that education fulfills the role of integral training with knowledge that is relevant to address students looking for alternatives to improve society (Aviles, 2019). Interrelating the term modernity from an educational perspective, it should be mentioned the importance that as teachers generate science and this focuses on the resolution of problems based on real research and in turn serves as a support for new studies in different contexts and with different situations

Moreira, M. T. V., Saldarriaga, A. M. V., Mendoza, G. K. Z., Santos, M. V. L., \& Loor, D. J. G. (2020). Implementation strategies for homework sent. International Research Journal of Engineering, IT \& Scientific Research, 6(1), 18-30. https://doi.org/10.21744/irjeis.v6n1.848 
The advances of Science and Technology play an indispensable role within the educational context, they are incorporated into the teaching-learning process as a proposal for change and conditioning to the requirements of society, facilitating access to information and the completion of tasks (Torres \& Cobo, 2017), states that the use of technological tools encourages the development of a nation and positively influences the economic, social, environmental and educational fields, ensuring changes and evolution of knowledge. The use of the Internet as a means of learning is a clear manifestation of the teaching of the current educational system, a proposal that provides mass information, resources, materials quickly and efficiently, its role is to share ideas and exchange knowledge, sharing the thinking of (Navarrete \& Mendieta, 2018), globalization creates connections that generate strategies aimed at the realization of projects, but there are specifically rural locations that lack resources, technological means, viability, and basic services, a reality that creates a disadvantage for educators and teachers being it is necessary to implement strategies to improve understanding and intellectual abilities within the classroom.

\subsection{Factors that influence within the current education}

One of the impediments to the achievement of quality education within the educational system is the different barriers imposed within the society, where economic and political aspects predominate that create disadvantages for low social classes causing school dropout, frustration and poor performance among other aspects. According to Tamayo (2019), it details that there are students with low economic level, however, it achieves the required results in academic performance compared to other students that come from homes with a high economic level. That is why, despite the fact that in many investigations it is emphasized that one of the factors that negatively affect education is the economic factor, as the years go by it is observed that it is not an affirmation, but that there are other aspects that they intervene directly in the limitation of achieving educational objectives.

International organizations work for teacher training, which raises issues related to the educational reality of Ecuador. Ortiz et al. (2017), states that the United Nations Educational, Scientific and Cultural (UNESCO) provides some aspects that influence the current teacher training, as detailed below in the figure (1).

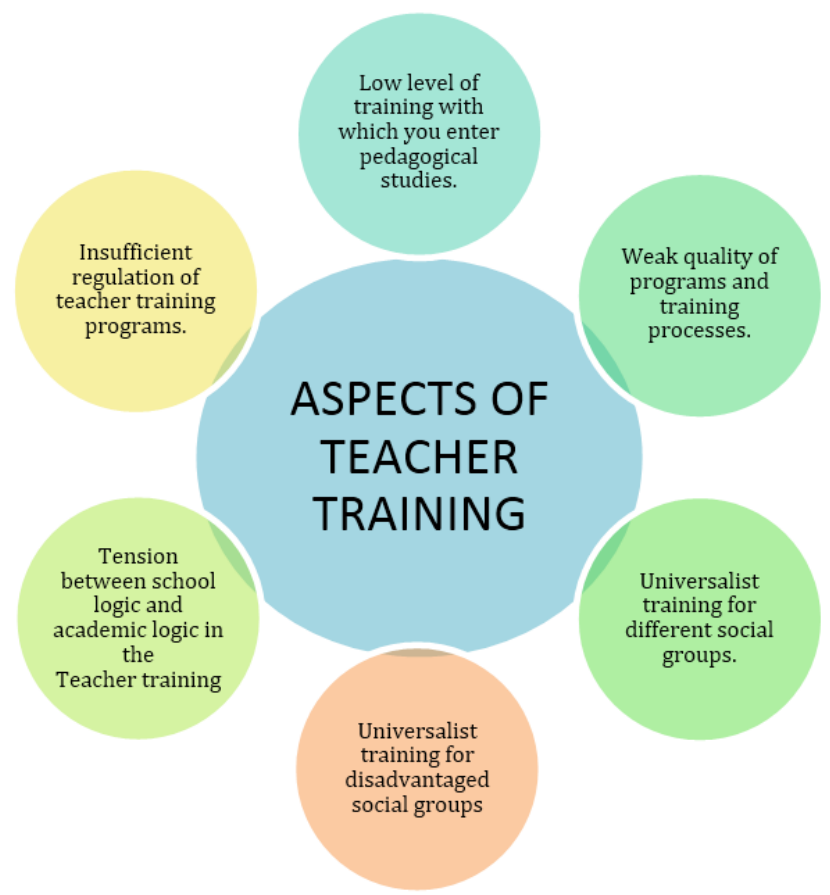

Figure 1. Aspects of teacher training

Source: (Ortiz et al., 2017)

All the aforementioned factors affect the teacher training and development they have in the classroom, everything is connected to the teacher's educational practice, which must connect all the aspects such as content, strategies, 
techniques, methods, and level of study; It is considered that teachers are responsible for training and educational quality that is desired.

The factors involved in the quality of education can be divided into either extra-school or intra-school, it is emphasized that currently, the educational curriculum is innovative that allows the educational community to increase ideas that counter ideas that hinder an education quality. According to Yao (2016), many of the factors that influence education and affect the development of society, state that students and teachers are the main factors and that any teaching strategy, administration or the educational environment influences academic activities; Below in Figure (2), essential factors for education teaching-learning are detailed:

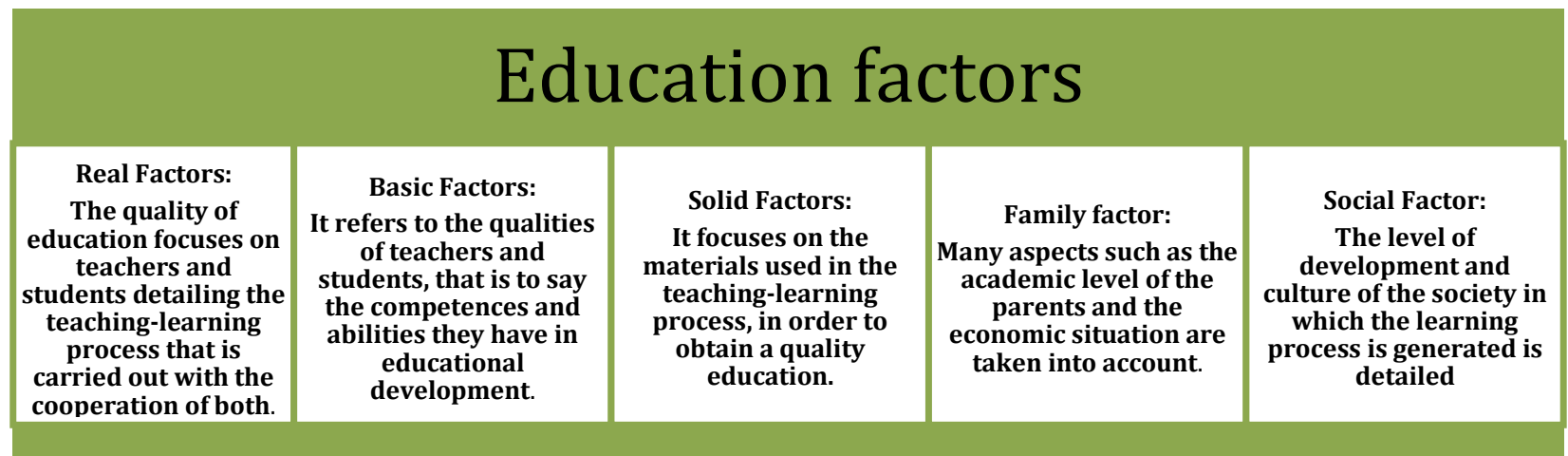

Figure 2. Factors of education

Source: (Yao, 2016)

People trained through education achieve the development of society, the factors have direct importance in education, being essential to mention the qualities of teachers and students attached to other elements that make up the idea of obtaining a quality education, which improves as science and technology advances, so it is used everything that is available and feasible to obtain the country with culture and suitable for future modifications, in this way to combat the negative aspects and not in accordance with the ethical and moral formation of society.

\section{Categorical Training, Non-Categorical Training, and Inclusive Training}

The dream of educational systems in the international arena is the inclusive training of teachers, to materialize this yearning would create a classroom that fully promoted equality and social justice. Inclusive education implies a rethinking of teacher training processes, Latin America, despite having some lag to the inclusive movement, has prioritized this issue in recent years, where authors such as Herrera et al., (2018), established through the following opinions, the importance of working under an educational system that fosters inclusion. Inclusive training is necessary as it would guarantee an education of excellence, without neglecting the educational formations that exist such as categorical and non-categorical.

The categorical training through the aforementioned research involves the training of professionals based on categories of deficits both around the organization of the curriculum, as well as the specializations. Starting from the previous approach, said training is in accordance with the educational model, which is lagging behind from inclusive practices where the dissonance of the categorical formative model is censored, it is evident that categorical training models fail to meet all the needs of students with disabilities.

In contrast to the type of training described recently, new proposals arise, such as non-categorical, crosscategorical, multi-categorical or polyvalent training. The objective pursued by said training is to develop specific and indispensable skills, abilities and competencies in the teaching staff for the achievement of school integration programs, the proposed competencies refer to contents, skills or didactic strategies for the development of the curriculum, the management of the class and the detection of SEN, focused on individual needs and not on their deficit condition, also offers training that prepares the teacher to attend children with a variety of characteristics.

Once the types of formations have been analyzed, we consider that the inclusion model is the right path towards 21st-century education, since it imposed a transition of cultural values and religious dogmas of charity and compassion at the expense of law, equity and social justice. In an analysis conducted on the situation of teachers in the face of inclusive education, the need to strengthen training is recognized by sharing the study of Rivera et al.

Moreira, M. T. V., Saldarriaga, A. M. V., Mendoza, G. K. Z., Santos, M. V. L., \& Loor, D. J. G. (2020). Implementation strategies for homework sent. International Research Journal of Engineering, IT \& Scientific Research, 6(1), 18-30. https://doi.org/10.21744/irjeis.v6n1.848 
(2019), where it establishes a substantial analysis that defines and guides inclusive education in the educational institutions, oriented from the disability, to develop assistance ideas and solution integrators.

Regarding the analysis carried out by Pinargote et al. (2016), it is determined that teachers act to improve inclusive practices, but the lack of pedagogical tools is a limitation, being necessary to develop skills, abilities, and knowledge of the processes of inclusive teaching and learning, where education actors analyze, discuss and seek solutions and explanations consistent with the practice with students with special educational needs.

The exploration of the national reality in Ecuador at the time of designing the Special Education career with an inclusive approach, allowed to verify a teacher training associated with heterogeneous degrees, curricula with little validation processes and updating of knowledge of science, profession, and the research, with modalities of qualification work that did not guarantee quality to achieve the profile of future professionals (Rivera et al., 2019), emphasizes that new forms of work in special education direct the participation of all students, training, skills and teaching skills that allow them to explain and understand the problems of reality understudy or intervention of the profession; Identify problems, tensions and dilemmas that define the axes of the research process, through skills of exploration, inquiry, organization, explanation, structuring and involvement with the problems of the investigated reality and object of transformation.

Teachers play an essential role in the goal of inclusive education since they are responsible for implementing these integration practices, to achieve a quality education system. Associating the ability to offer the same training and development opportunities to all students, based on the principles of equity and equality.

\subsection{Educational policies of the last decade}

In the last government administrations of the country, the strong economic investment that was made in the educational infrastructure with the so-called 21st century and millennium schools can be mentioned as relevant, which in one way or another improved the environment school and continuous learning due to the implementation of technological laboratories, chemists, workshops for technical areas and the basic tool such as the internet. It is important to consider the sequential changes that occurred with the 10-year plan, as a result of improving the educational curriculum, with the implementation of both face-to-face and virtual teacher training, the proposal to provide technological resources allowed interacting in different areas, improving communication and creating a link between human beings and scientific research, encouraging teamwork, commitment to students in providing a highlevel education through the exchange of ideas, expression of values, emotion control and the management of various computer tools create an integral learning (Paladines, 2015).

Ecuador has implemented educational reforms, seeking the quality of the teaching-learning process, supporting the most vulnerable sectors so that students can access free training, social construction that focuses on cognitive development together with cross-cutting axes, compatible with identity Cultural of the peoples (De la Hérnan et al., 2018), details that the protagonist of the educational sector are teachers and students, a sense that accredits a planning system to provide initial and continuous training of teachers. The planning process of each educational system is diverse, due to focused realities within different contexts and particular characteristics, (Castro et al., 2016), assumes that current educational advances within the country show positive changes, a situation that It presents the development of strategies and action policies aimed at guaranteeing the achievement of training quality professionals, where infrastructure swaps are exposed, opening of recreational activities within the curriculum, constant evaluation to determine if learning is significant and technological advances, These factors determine improvements to become an educational reference.

The new Ecuadorian educational system implies transcendental changes that seek to implement a curricular reform within the classroom, strengthening academic levels to avoid the failure that is linked to school dropout, a situation that leads to improved student performance (Martínes \& Sánchez, 2018) determines that the training must be dynamic, creative, continues linked to the competences of each individual, where the teacher is a guide of knowledge, from the pedagogical point of view it meets the perspectives of the student according to the socioeconomic needs and educational being critical and autonomous to solve study problems linked to the reality of the context (Mendoza \& Rodríguez, 2020). Due to the academic challenges that arise, a new open and flexible curriculum is established, based on the participation of the educational community to respond to specific needs, generating the socialization of changes to specifically know the fields in which they are it must improve and apply corrective measures that validate the adjustments currently established in the training (Vera, 2015), confirms the state's support for schools, colleges and universities, a priority that allows us to envision quality education where the education plan is to continually prepare to teachers and thus constitute school improvement. 


\section{Educational reforms}

Education in Ecuador due to the lack of economic resources and consequently due to the lack of preparation of those who make up human talent, no feasible project could be carried out (Aguilar, 2019), states:

In the first decade of the following century, with the constitution of 1907, the Church-State separation is established. The functions that correspond to the State and the tasks that concern the Church are defined. It begins to generate, in a disorderly way, a new educational process that had as a principle the knowledge in a utilitarian way, new problems begin to arise. The Alfaro Government to organize an effective model, which is not threatened by religious practices, creates the normal in Quito, Guayaquil, and Cuenca to train teachers who teach a secular education (p.14).

In the analysis of the characteristics of the evolution of education in Ecuador, a model is established to understand the educational ideal and transform current education. This educational orientation is aimed at the cultural development of society, as historically since the presidency of Juan José Flores, where education was a privilege and not a right of all.

This is where the precedence of secular education in the García Moreno government takes a European educational model where the Jesuits were incorporated to give teaching where analysis, criticism or reflection was not allowed, on the other hand, the theocratic tendency was gaining strength and it accentuated. After the cycle of several presidents, education improved, guaranteeing significant advances that became the basis of education in the history of Ecuador.

\section{Interculturality, Plurinationality and SUMAK KAWSAY in Ecuador}

In the last decades of the history of Ecuador as a significant event has been the consolidation of the indigenous movement with the purpose of creating an equal and just society. (Rodríguez, 2017) states:

The first time this term appeared was in an unpublished manuscript by Carlos Viteri, a Kichwa indigenous from Sarayacu (Pastaza province), entitled "Indigenous vision of development in the Amazon" and published in 2002 in the Polis Magazine. The sumak kawsay is a radically different paradigm to the western one where life is interpreted holistically so that Nature, person and society are intimately articulated and a subject-object distinction between these categories is not possible (p.73). Sumak Kawsay has as its purpose a harmonious coexistence between the different cultures that make up the Ecuadorian territory in such a way that an inter-learning is promoted, and it is here that multinationality and interculturality promote a uninational and culturally uniform society since bilingual intercultural education is assumed for the state. These structures seek a social, cultural, political and economic transformation in order to reproduce a cultural homogenization that transmits a language that describes cultural and ethnic diversity, therefore, plurinationality induces a change for development and awareness of the reality of the country and that education has a strategic role for the dissemination of these values.

\section{Characteristics of the education of SUMAK KAWSAY in Ecuador}

The concept of good living has as its fundamental axis to bet on a new form of coexistence that one wants to propose in Ecuador. (Lara \& de la Herrán, 2016), state:

Therefore, as regards a possible approximation of what Ecuadorian educational reality can entail or how it should be done in relation to the above, it is understood as an education that aims to prepare people to live in a society in which the other or knowing how to live with the other implies the attitude of being affected by "our" culture and "their" culture, the "different", and their "differences" in terms of equality, through a necessary promotion of intercultural dialogue; interculturality, therefore, is conceived as a precise necessary quality so that the human being (understood as a complex reality) is willing to learn and teach in the process of intercultural dialogue (p.46).

Interculturality and its cultural reality are perceived as a central mechanism of learning imply a necessary meditation on the relationship between man and society with nature because Pacha Mama requires guaranteeing and protecting the country's educational political culture, in turn fostering critical thinking, citizen and ecological awareness in order to integrate nature. For the construction of interculturality in good living, a position is needed for the implementation of pedagogies that, based on the equality and diversity of cultures, require alternatives that give

Moreira, M. T. V., Saldarriaga, A. M. V., Mendoza, G. K. Z., Santos, M. V. L., \& Loor, D. J. G. (2020). Implementation strategies for homework sent. International Research Journal of Engineering, IT \& Scientific Research, 6(1), 18-30. https://doi.org/10.21744/irjeis.v6n1.848 
meaning to an adequate didactic of the right to education, since here it is where there is the main difficulty, therefore, the educational landscape goes in search of the quality of education and the link with society.

"A lifetime" implies an integrative approach so that no person is left out in order to achieve equality and equity in order to eradicate poverty, guaranteeing the rights of the people, which can be exercised through public power and participation of the constitution without any discrimination. This plan is aimed at ensuring that the proposals already made are fulfilled, in this way the living conditions of Ecuadorians, especially those in need (National Secretariat of Planning and Development, Senplades, 2017). Ensuring sustainability, this plan seeks to strengthen the economic and social system of Ecuador.

As its goal is to contribute to the fulfillment of rights, economy and with me society avoiding inequities by guaranteeing a dignified life with opportunities for everyone, both in the workplace, community, health and intercultural, in the educational field it seeks to eradicate illiteracy, also prevention and eradication of drug use and consumption. Consequently planning in the medium and long term national development to improve the quality of life of Ecuadorians. With this plan, President Lenin Moreno seeks sustainability, strengthening a fair, stable and decent work, encouraging citizens to be more active and participatory, providing a transparent quality of life for the strategic development of the country and the fight against corruption. In this way, the need for productivity and competitiveness levels for economic - sustainable growth of the country will be marked along with the contribution and active participation of each citizen.

\subsection{Alternative solutions}

According to Sanabria (2013), he mentions that educational practices are complex because social demands, policies and institutional desires are articulated, also links with the institution and the professional career of teachers, student capacities and different elements within the classroom. The new advances provide positive solutions for the improvement of pedagogical practice in order to meet the expectations that education currently has, is to train leaders who develop in all fields efficiently and solve problems within a context determined, as well as positive contributions to society morally focused on the continuous work of values within the educational system and its application in daily life.

Current education must form an individual who has a purpose in life and shows an attitude with the potential to face different problems of society. Incorporating technologies into processes is forcing changes in teaching strategies and learning processes (García Aretio, 2017). In order to adapt the different ways of teaching and learning by innovating significantly and leaving behind traditional ways, in this way to solve the problems of education, improve the academic level and encourage the use of digital resources and platforms in educational environments.

It is essential to contextualize teacher participation and training as a primary axis to achieve pedagogical progress, it is also necessary to provide programs, entrepreneurship workshops, recreational activities, educational projects, scientific programs, and innovation to empower the educational community to achieve an academic level of Quality, directing knowledge to meaningful learning (Delgado et al., 2018), establishes that the school must work in an active and updated line of training, integrating all actors in recreational and cultural activities to change that entrenched paradigm from the traditional towards a space of the school of the 21 st century, which evidences the invention, creativity, the use of methodologies and strategies according to the skills of the students.

Transforming education is a social challenge, where teachers together with students and parents must be promoters of changes, linking the teaching-learning process as a basis for quality integral education, an event that manifests various problems that negatively influence The education system, (Bravo et al., 2017), indicates that students are immersed in complex situations in the daily life, considering bad attitudes due to intrafamily problems and emotional illiteracy, which directly affect the school level that students can reach, causing school dropout, behavioral problems among other manifestations that are common actions among individuals who grow up in similar situations, the situation promotes working together for educational progress where ethical and moral values are strengthened. In figure (3), the actors involved in the current education system are represented. 


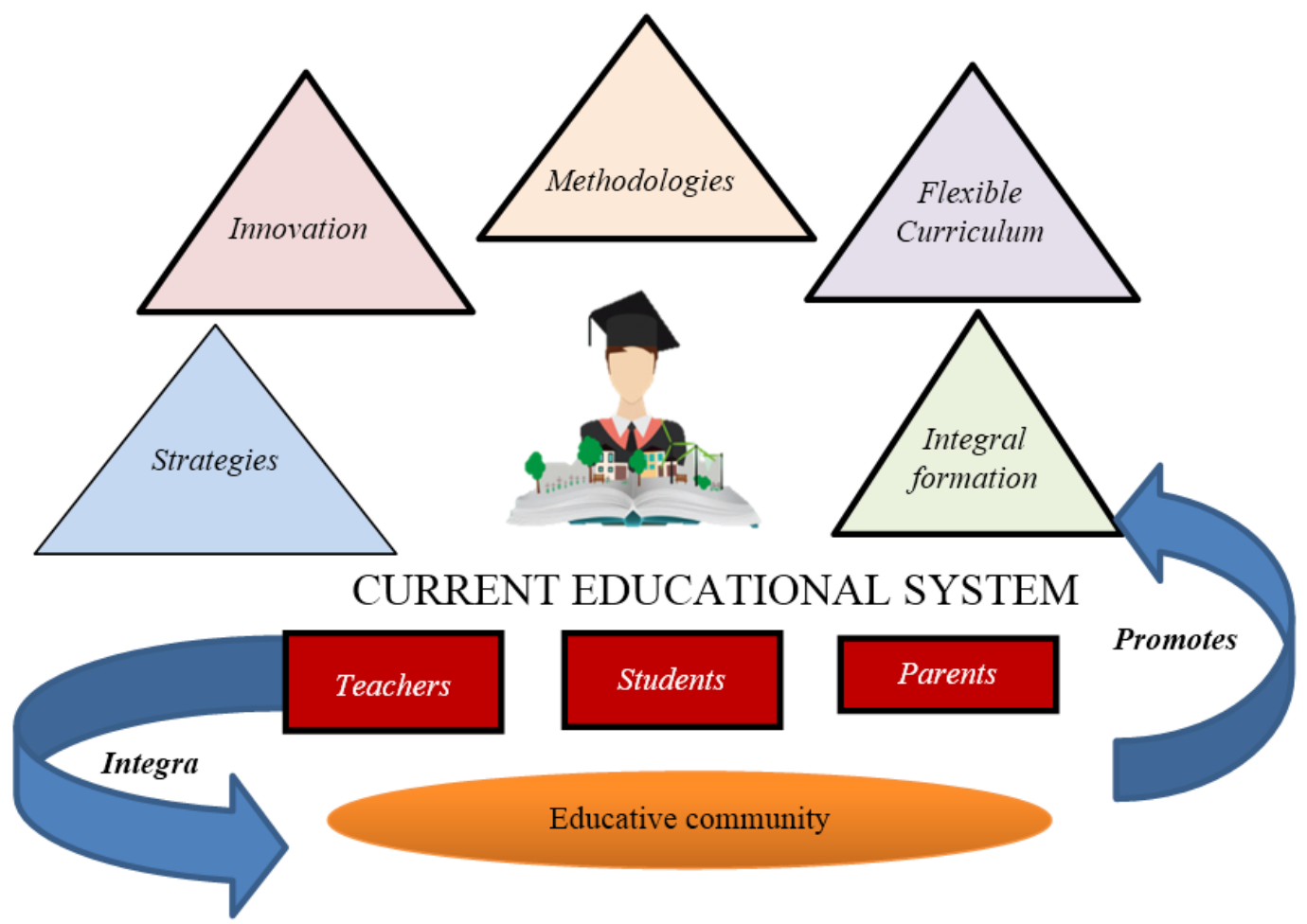

Figure 3. The actors involved in the current education system

\section{Conclusion}

There are countless problems at the international level that are not alien to our national and local reality, which reflects the importance of research to make sound decisions in the educational field. Parents and teachers are those who have the moral responsibility to guide and stimulate children and young people in the insertion and good development within the educational process, giving it the true importance that it has, in order to improve society. Knowing the educational reality of the environment allows looking for new teaching strategies and assessment of the education system, supported by the innovative and recent curricular reforms of the country.

\section{Conflict of interest statement}

The authors declared that they have no competing interests.

\section{Statement of authorship}

The authors have a responsibility for the conception and design of the study. The authors have approved the final article.

\section{Acknowledgments}

We are grateful to two anonymous reviewers for their valuable comments on the earlier version of this paper.

Moreira, M. T. V., Saldarriaga, A. M. V., Mendoza, G. K. Z., Santos, M. V. L., \& Loor, D. J. G. (2020). Implementation strategies for homework sent. International Research Journal of Engineering, IT \& Scientific Research, 6(1), 18-30. https://doi.org/10.21744/irjeis.v6n1.848 


\section{References}

Aguilar-Gordón, F. D. R. (2019). Fundamento, evolución, nodos críticos y desafíos de la educación ecuatoriana actual. Actualidades Investigativas en Educación, 19(1), 720-752. http://dx.doi.org/10.15517/aie.v19i1.35715

Alava, E. E., \& Martinez, M. E. M. (2019). Impact of teaching-learning process for brain. International Journal of Health Sciences, 3(1), 33-40. https://doi.org/10.29332/ijhs.v3n1.304

Avilés, M. (2019). Estrategias para salir de la modernidad, la necesidad de un giro epistemológico y educativo para superar la crisis. Revista Andina de Educación., 2(2), 2-14. Obtenido de https://revistas.uasb.edu.ec/index.php/ree/article/view/668

Bravo Vélez, L. E., Amayuela Mora, G., \& Colunga Santos, S. (2017). Tendencias históricas del proceso de educación emocional en los estudiantes del bachillerato en Ecuador. Mendive. Revista de Educación, 15(3), 305315.

Castro, S., Chiluisa, M., Borja, G., \& González, L. (2016). La calidad de la educación en las instituciones de educación superior bajo una nueva reforma curricular. Revista Boletín Redipe, 5(12), 86-95.

De la Hérnan, A., Ruiz, A., \& Lara, F. (2018). Claves del cambio educativo en Ecuador. Foro de Educación, 16(24), 141-166. doi:http://dx.doi.org/10.14516/fde.516

Delgado, J., Vera, M., Cruz, J., \& Pico, J. (2018). El currículo de la educación básica ecuatoriana: una mirada desde la actualidad. Revista Cognosis, 3(4), 47-66. Obtenido de https://186.46.160.238/index.php/Cognosis/article/view/1462/1718

Diaz, J. (2018). La Educación Superior dentro de la realidad nacional ecuatoriana contempoánea. Espacios, 39(20 ), 1-15. Obtenido de https://www.revistaespacios.com/a18v39n20/a18v39n20p24.pdf

Erreyes, HM, García, TM, \& Zurita, GE (2017). La realidad educativa ecuatoriana desde una perspectiva docente. Revista Iberoamericana de Educación, 75(2), 9-20. Obtenido de https://rieoei.org/RIE/article/view/2629

Fernandez, M., Alcaraz, N., \& Sola, M. (2017). Evaluación y Pruebas Estandarizadas: Una reflexión sobre el sentido, utilidady efectos de estas pruebas en el campo educativo. Revista Iberoamericana de Evaluación Educativa., 10(1), 51-67. Obtenido de https://revistas.uam.es/index.php/riee/article/download/7594/7893

García Aretio, L. (2017). Educación a distancia y virtual: calidad, disrupción, aprendizajes adaptativo y móvil. Revista Iberoamericana de Educación a Distancia, 20, 9-25. Obtenido de https://www.redalyc.org/pdf/3314/331453132001.pdf

Granda, J. (2018). Transformaciones de la educación comunitaria en los Andes Ecuatorianos. Sophia: colección de Filosofía de la Educación., 24(1), 291-311. Obtenido de http://scielo.senescyt.gob.ec/pdf/sophia/n24/1390-8626sophia-24-000291.pdf

Hernández, M. (2015). El diagnóstico educativo, una importnate herramienta para elevar la calidad de la educacíon en manos de los docentes. Atenas, 3(31), 63-74. Obtenido de https://www.redalyc.org/pdf/4780/478047207007.pdf

Hérnandez, R., Fernández, C., \& Baptista, M. (2010). Metodología de la Investigación. México: Mc Graw Hill. Obtenido https://www.esup.edu.pe/descargas/dep_investigacion/Metodologia\%20de\%201a\%20investigaci\%C3\%B3n\%205 ta\%20Edici\%C3\%B3n.pdf

Herrera, J., Parrilla, A., Blanco, A., \& Guevara, G. (2018). La Formación de Docentes para la Educación Inclusiva. Un Reto desde la Universidad Nacional de Educación en Ecuador. Revista Latinoamericana de Educación Inclusiva, 12(1), 21-38. Obtenido de https://scielo.conicyt.cl/pdf/rlei/v12n1/0718-7378-rlei-12-01-00021.pdf

Isch, E. (2011). Las actuales propuestas y desafíos en educación: el caso Ecuatoriano. Educação \& Sociedade, 32(115), 373-391. Obtenido de https://www.redalyc.org/pdf/873/87319092008.pdf

Klaric, J. (Dirección). (2017). Un crimen llamado educación [Película]. México. Obtenido de https://www.youtube.com/watch?v=7fERX0OXAIY

Lara, F., \& de la Herrán, A. (2016). Reflexiones sobre la educación del sumak kawsay en Ecuador. Araucaria. Revista Iberoamericana de Filosofía, Política y Humanidades, 18(36), 41-58. Obtenido de https://www.redalyc.org/pdf/282/28248171003.pdf.

López, M.; Vegas, H. \&Rodriguez, M. (2020). Project-based Learning Strategy: An Innovative Proposal for Local Education System. International Journal Of Psychosocial Rehabilitation. ISSN: 1475-7192 ISSUE 1, Vol. 24. https://doi.org/10.37200/IJPR/V24I1/PR200267.

Macías, E. I. P., Cedeño, H. A. C., \& Chávez, G. M. R. (2018). Importance of Improving Resilience in TeachingLearning Process of Students with Disabilities. International Research Journal of Management, IT and Social Sciences, 5(2), 120-128. 
Martínes, J., \& Sánchez, S. (2018). Generación de competencias con base en la gestión de conocimiento científico. Revista Iberoamericana sobre Calidad, Eficacia y Cambio en Educación., 16(2), 61-76. Obtenido de https://repositorio.uam.es/bitstream/handle/10486/681602/REICE_16_2_4.pdf?sequence=1\&isAllowed=y

Martínez, M., \& Torrego, J. (2014). Programas y medidas educativas en España para alcanzar objetivos europeos. REDIE. Revista Electrónica de Investigación Educativa., 16(2), 119-134. Obtenido de https://www.redalyc.org/pdf/155/15531719008.pdf.

Mendoza, M. \& Rodríguez, M. (2020). Student-centered learning from research planning. Revista Interdisciplinaria de Humanidades, Educación, Ciencia y Tecnología Año Vl. Vol. Vl. N¹0. Enero - Julio 2020 Hecho el depósito de ley: pp201602FA4721 ISSN-L: 2542-3029; ISSN: 2610-802X. cienciamatriarevista.org.ve.

Meneses, I.; Moya, M. \& Rodríguez, M. (2020). Influence of Videogames on Student Behavior. International Journal Of Psychosocial Rehabilitation. ISSN: 1475-7192 ISSUE 1, Vol. 24. https://doi.org/10.37200/IJPR/ V24I1/PR200267.

Merchán, J. (2018). Transformaciones de la educación comunitaria. Sophia: colección de Filosofía de la Educación, 24(1), 291-311. Obtenido de http://scielo.senescyt.gob.ec/pdf/sophia/n24/1390-8626-sophia-24-000291.pdf

Murillo, J., \& Garrido, CM (2019). Una Mirada a la Investigación Educativa en América. Revista Iberoamericana sobre Calidad, Eficacia y Cambio en Educación, 17(2), 5-25. Obtenido de https://revistas.uam.es/index.php/reice/article/view/reice2019.17.2.001/10787

Navarrete, G., \& Mendieta, R. (2018). Las Tics y la educación ecuatoriana en tiempos de internet: breve análisis. Espirales. Revista Multidisciplinaria de Investigación, 2(15), 123-136. Obtenido de https://revistaespirales.com/index.php/es/article/download/220/165

Ortiz, M., Fabara, E., Villagómez, M., \& Hidalgo, L. (2017). La formación y el trabajo docente en el Ecuador. Quito, Ecuador: 1 Abya-Yala. Obtenido de https://dspace.ups.edu.ec/bitstream/123456789/14919/1/La\%20formacion\%20y\%20el\%20trabajo\%20docente\%2 0en\%20el\%20Ecuador.pdf

Paladines, C. (2015). Perspectivas de cambio en la Educación Básica y en el Bachillerato. Ecuador: 2007-2013. 19(3), 13-31. Obtenido de https://www.redalyc.org/pdf/1531/153143329002.pdf

Pinargote, M., García, P., Véliz, V., de la Hérran, A., Aveiga, V., \& Villavicencia, I. (2016). Investigaciones, experiencias y propuestas para la educación inclusiva en la universidad. Portoviejo, Ecuador: Universidad Técnica de Manabí. Obtenido http://utminclusiva.com/wpcontent/uploads/2019/03/Investigaciones_experiencias_y_propuestas_para_la_educacion_inclusiva_en_la_univer sidad_978-9942-948-04-5.pdf

Rivera, M., Coello, J., \& Moran, M. (2019). Las prácticas inclusivas en el proceso educativo de alumnos con necesidades educativas especiales. ¿Cuestión de teorías de aprendizaje? En C. Pavón, Primer congreso internacional en Ciencias de la Educación CICE 2018. Guayaquil, Ecuador: Grupo Compás.

Rodríguez, M. (2017). Interculturalidad, plurinacionalidad y sumak kawsay en Ecuador. La construcción de un nuevo modelo de Estado a través de la educación intercultural bilingüe: discurso y realidad. Perfiles educativos, 39(157), 70-86. Obtenido de http://www.scielo.org.mx/pdf/peredu/v39n157/0185-2698-peredu-39-157-00070.pdf

Salgado, S. (2016). Influencia de la visión mercantilista en el proceso educativo en escuelas privadas del Ecuador. Estudio aplicado a cinco unidades educativas privadas del sector de Tumbaco. Pontificia Universidad Católica del Ecuador, Tesis de posgrado, Tumbaco, Quito. Obtenido de http://repositorio.puce.edu.ec/bitstream/handle/123456789/13057/tesis\%204.pdf?sequence=1\&isAllowed=y

Sanabria, M. (2013). La teoría de las inteligencias múltiples desde la perspectiva del asesoramiento psicopedagógico en el contexto educativo. Revista espiga, 25, 33-50. Obtenido de https://www.redalyc.org/pdf/4678/467846257003.pdf

Secretaría Nacional de Planificación y Desarrollo, Senplades. (2017). Plan nacional para el buen vivir 2017-2021. SENPLADES, Quito, Ecuador.

Tamayo, T. (2019). El sistema educativo de Ecuador: un sistema, dos mundos. Revista Andina De Educación, 2(1), 8-17. Obtenido de https://revistas.uasb.edu.ec/index.php/ree/issue/view/26312816.2019.2.1/2

Torres, P., \& Cobo, J. (2017). Tecnología educativa y su papel en el logro de los fines de la educación. Educere, 21(68), 31-40. Obtenido de https://www.redalyc.org/pdf/356/35652744004.pdf

Vera, M. (2015). Reformas educativas en el Ecuador. Revista Boletín Redipe, 4(8), 17-34. Obtenido de https://dialnet.unirioja.es/descarga/articulo/6245332.pdf

Yao, F. (2016). Los factores que influyen en la calidad de la educación. Itinerario Educativo, 67, 217-225. Obtenido de https://revistas.usb.edu.co/index.php/Itinerario/article/view/2898/2492

Moreira, M. T. V., Saldarriaga, A. M. V., Mendoza, G. K. Z., Santos, M. V. L., \& Loor, D. J. G. (2020). Implementation strategies for homework sent. International Research Journal of Engineering, IT \& Scientific Research, 6(1), 18-30. https://doi.org/10.21744/irjeis.v6n1.848 


\section{Biography of Authors}



